\title{
Investigation on Practice Teaching Mode of Business Administration
}

\author{
Jiang Yan
}

\author{
Nanchang Institute of Science \& Technology
}

\author{
Keywords: Business Administration; Practice teaching, Creation; ERP
}

\begin{abstract}
With the rapid development of our social and economy, it puts forward higher requirement to the quality of business administration talents .However, due to the deficiency of traditional teaching method, there is a common problem existing in undergraduates that they attach great importance on theory and take no account to skills and application ability. In order to meet the society's demand to practicality and creativity of business administration professionals, it urgently needs to change the existing practice teaching mode. It put forward practice teaching content and teaching method according to the existing problems, take ERP sandbox course of business administration for example , analyzed its unique teaching content and teaching method, thus put forward innovation design based on systematic thinking system in business administration undergraduate stage.
\end{abstract}

\section{Introduction}

Entering the new century, with the increasingly intensified economic globalization and the increasingly uncertainty of environmental changes. Our country is eager for more high-quality application business administration talents. However, there is a structural contradiction between college business administration education and current demand to business administration talents.

A large number of investigations show that in many fields of industry, serious problems exists in business administration majors in terms of knowledge application and transformation, even the high level business administration majors are neither able to apply specific expertise well to successfully operate enterprises of computer dynamic simulation, nor they are able to rapidly adapt to specific management context based on declarative theoretical knowledge learned in textbooks .For example: it's the case happened in international business management challenge held in China for many years. The knowledge application of business administration majors not only is a lack of flexibility but also existing problems in knowledge division and integration. In general, although business administration majors have years of formal training in college, they are still subject to great distress--most of the knowledge they have mastered is "inert" knowledge.

The author believes that the root of these phenomena is that the students of this major lack of effective centralized practice teaching in education phase. As a result, practice teaching reform is imminent.

\section{The Importance of Centralized Practice Teaching of Business Administration}

Due to no contact with actual enterprise, business administration students have great difficulty in understanding the related variables and theory in textbooks. In many cases, they have to learn by rote and apply the knowledge inflexibly more or less. Therefore, the centralized practice teaching is particularly important. Its value lies in it allows students to combine study with work and it extends classroom teaching to practice application thus enrich the existing teaching system.

Facing new challenges of the progress of times, the essence of management is innovation, so is business administration. The key of cultivating high-quality professional talents of business administration lies in talents dare to innovate and be good at innovating. Whether there is innovation and whether innovation can be carried on are the decisive factors to grab applied management talents worldwide. The innovation ability cultivation of management talents is not in theory teaching, nor in laboratory, but depends more on practice teaching .In centralized practice 
teaching, teachers often give students specific management situation or actual problems needed to solve, which have great uncertainty. Thus it requires students to utilize comprehensively various types of knowledge, together with logical thinking and divergent thinking, as well as rational thinking and confusing thinking, even brainstorming. This kinds of teaching mode is bound to maximally exercise students' creativity and cultivate the innovative business management talents urgently needed by modern society and enterprises.

Finally, the subject task assigned in centralized practice teaching usually requires teamwork and collaboration for successful completion. This requires to strengthen the relationship between students as well as the relationship between students and teachers. The formation process of this close relationship will help to cultivate the communication ability of each student and cultivate their interpersonal skills.

\section{Existing Problems of Business Administration Practice Teaching}

Emphasize "Quantity" not "Quality". The key to cultivate high quality talents lies in inspiring think and practice teaching is its means and carrier. At present, some colleges continue to expand the scale of enrollment, directly leading to the insufficiency of practice teaching venue, equipment, personnel and finds. The contradiction between limited education resources and requirement of practice teaching quality are increasingly deep, thus the circumstance of emphasizing "quantity" not "quality" occurs. It's greatly reduced in actual execution.

Teaching Method and Teaching Means Homogeneous. As a highly professional major, business administration must be closely linked with the practice of our country. But the course learning of current business administration is basically only in class, with modern education technology seldom used. Laboratory construction and practice construction in some colleges are seriously lagging behind. The combination of industry, university and research is not tight enough. Innovation is not much but many foreign ready-made theories.

Emphasize theory teaching, inadequate practice teaching experience and facilities. The existing business administration teaching task emphasizes theoretical knowledge and ignores the cultivation of practical operation ability. At present, many undergraduate universities and colleges have increased the ratio of practice teaching in business administration specialty construction process, but due to the limited class hour and teachers' practice experience, in the talent training mode it still generally follow the traditional cultivation mode of "learning theory, centralized practice and graduation practice", resulting in students' weak practice ability. The practicability of professional is greatly reduced.

\section{Business Administration Teaching Innovation}

Teaching Idea Innovation. Practice teaching in college is to continue, expand and deepen the theory teaching. The practice teaching of business administration should pay more attention to the application and innovation of theoretical knowledge, and focus on building relatively independent practical teaching system which equals to theoretical teaching. Therefore, the practice teaching of business administration need establish a "student-centered, strengthening knowledge and skills and cultivating practical innovative talents" teaching philosophy.

Teaching Contents Innovation. Since the teaching material itself has certain hysteresis and limitation, the teaching contents innovation of business administration is to ask teachers to reform teaching contents when using teaching materials, highlight the "four modernizations", namely the backgrounding of the teaching contents, the processing of the teaching contents, the novelty of the teaching contents and the application of the teaching contents.

Teaching Method Innovation. Matching with the teaching content and method of ERP sandbox course is the innovation of game simulation and the application of information teaching means. The use of large number of information technology education is helpful to improve the teaching 
efficiency. But sometimes the students will have a "computer fatigue" causing the learning efficiency decreased. ERP course makes the theoretical knowledge and related knowledge throughout the curriculum, by means of sandbox simulation exercises, ERP theory, enterprise behavior simulation and so on to simulate enterprise operation process in virtual environment. Make the operation process games and ask students to take part in and it will greatly stimulate students' interest in learning thus deepens students' understanding and application ability of knowledge.

\section{Conclusion}

It's the primary objective to cultivate innovative talents in various colleges and universities. The characteristics of business administration also decide that in new era, we must pay attention to the practice settling in cultivating innovative talents. Although colleges have been in the exploration, expecting to establish a set of business administration innovative talents cultivation mode which is suitable for China's actual condition. But due to the limits of traditional teaching mode and practice teaching investment and so on, at present there are still many problems in cultivation process of business administration innovative talents.

The design of ERP sandbox course business administration course system of this paper is based on the actual education system in China, make full use of the school time of students and adjust and optimize and setting of curriculum. The innovation of business administration is based on the business administration undergraduate practice teaching innovation design cultivated by systematic thinking system.

\section{References}

[1] Kong L Y. Discussion on concentrated practice teaching reform of business administration major [J]. Journal of Xian University of Posts \& Telecommunications, 2011.

[2] Wang Y. Discussion on The Practice of the PBL Teaching Mode Through Educational Network [J]. Journal of Guangdong Radio \& Tv University, 2003.

[3] Guo Y, Lin K, Tan Y. Discussion on the Internal Medicine of Traditional Chinese Medicine Practice Teaching 1+1 Mode to Cultivate TCM Clinical Thinking Ability[J]. Journal of Chengdu University of Traditional Chinese Medicine, 2012.

[4] Xie X Y. Exploration of the establishing of practice teaching mode of the major of business administration [J]. Journal of Fujian Agriculture \& Forestry University, 2008.

[5] Yang N. Discussion on the Teaching Mode of P.E. and Essential Teaching [J]. Journal of Beijing Teachers College of Physical Edueation, 2000.

[6] Bertrand L. Cooperation between a Distance Teaching University and an On-Campus University: The Creation of a Dual-Mode University [J]. Global Challenges \& Perspectives in Blended \& Distance Learning, 2013.

[7] Chen J. Discussion on the Reform of Training Mode of Teaching Software [J]. Value Engineering, 2013.

[8] Stark R. Implementing Example-Based Learning and Teaching in the Context of Vocational School Education in Business Administration [J]. Learning Environments Research, 2004, 7(7):143-163.

[9] Li Y U, Business S O. On Fundamental Theories and Research Methodology of the Discipline of Business Administration [J]. Economic Management Journal, 2013.

[10]Grollmann P. First results from a comparative study on the professional reality of vocational teachers [J]. Cedefop, 2002.

[11]Joyce B, Calhoun E. The Conduct of Inquiry on Teaching: The Search for Models more Effective than the Recitation [M]// The Practice and Theory of School Improvement. Springer Netherlands, 2004:182-207.

[12]Yu S J. A Study on Practical Teaching System of Business Administration Major[C]// 2015 International Conference on Management Science and Management Innovation (MSMI 2015). 
Atlantis Press, 2015. 